\title{
PEMANFAATAN WHATSAPP GROUP SEBAGAI SARANA KOMUNIKASI GURU DAN ORANGTUA SISWA SELAMA MASA PANDEMI COVID 19
}

\author{
Dwhy Dinda Sari \\ IAIN Lhokseumawe \\ email : $\underline{\text { dwhydinda@gmail.com }}$
}

\begin{abstract}
Abstrak
Perkembangan teknologi yang semakin canggih memberikan dampak positif dalam kehidupan termasuk dalam kegiatan komunikasi. Aplikasi Whatsapp termasuk aplikasi yang paling banyak digunakan pada masa sekarang. Semua tingkatan umur dan profesi sudah tidak asing lagi dengan penggunaan Whatsapp. Penelitian ini bertujuan untuk mengetahui karakteristik penggunaan WhatsApp dan mengetahui pemanfaatan media sosial grup WhatsApp pada orang tua dan guru PAUD sebagai media komunikasi. Metode yang digunakan dalam penelitian ini yaitu deskriptif kualitatif dengan mendeskripsikan, mencatat, menganalisis dan menginterpretasikan kondisi yang sedang terjadi. Hasil penelitian menunjukkan bahwa pemanfaatan media sosial grup Whatsapp di PAUD sangat besar. Selain berfungsi untuk menyampaikan informasi, grup WhatsApp juga berfungsi sebagai media diskusi dan media saling berbagi, sebagai media hiburan dan sebagai media yang dapat digunakan orang tua untuk memantau anak saat di sekolah.
\end{abstract}

Kata Kunci : Grup Whatsapp, orang tua, guru

\begin{abstract}
The development of increasingly sophisticated technology has a positive impact on life, including in communication activities. The Whatsapp application is one of the most used applications today. All ages and professions are familiar with the use of Whatsapp. This study aims to determine the characteristics of the use of WhatsApp and to determine the use of WhatsApp Group social media in PAUD parents and teachers as a medium of communication. The method used in this research is descriptive qualitative by describing, recording, analyzing and interpreting the conditions that are happening. The results showed that the use of the WhatApp Group social media in PAUD was very large. Apart from serving as a function of conveying information, WhatsApp Group also functions as a medium for discussion and a medium for sharing, as a medium of entertainment and as a medium that parents can use to monitor their children while at school.
\end{abstract}

Keywords: Whatsapp group, parents, teacher 


\section{Pendahuluan}

Pasal 1 ayat 1 Undang-Undang RI No 20 tahun 2003 tentang sistem pendidikan nasional yang menyatakan:"Pendidikan adalah usaha sadar dan terencana untuk mewujudkan suasana belajar dan proses pembelajaran agar peserta didik secara aktif mengembangkan potensi dirinya untuk memiliki kekuatan spiritual keagamaan, pengendalian diri, kepribadian, kecerdasan, akhlak mulia, serta ketrampilan yang diperlukan dirinya, masyarakat, bangsa, dan negara"[1]. Sekolah adalah lembaga formal yang dapat membantu mewujudkan sumber daya manusia sesuai dengan yang diharapkan sistem pendidikan nasional. Maka dari itu perlu adanya kerjasama antara semua komponen penyelenggara Pendidikan seperti kepala sekolah, guru, orangtua dan masyarakat sekitar.

Pendidikan anak usia dini (PAUD) adalah jenjang pendidikan sebelum jenjang pendidikan dasar yang merupakan suatu upaya pembinaan yang ditujukan bagi anak sejak lahir sampai dengan usia enam tahun yang dilakukan melalui pemberian rangsangan pendidikan untuk membantu pertumbuhan dan perkembangan jasmani dan rohani agar anak memiliki kesiapan dalam memasuki pendidikan lebih lanjut, yang diselenggarakan pada jalur formal, nonformal, dan informal [2]. Tujuan Pendidikan Anak Usia Dini (PAUD) menurut Undang-Undang nomor 20 tahun 2003 tentang sistem pendidikan nasional dinyatakan bahwa pendidikan anak usia dini adalah sebagai suatu upaya pembinaan yang ditujukan kepada anak sejak lahir sampai dengan usia enam tahun yang dilakukan melalui pemberian rangsangan pendidikan untuk membantu pertumbuhan dan perkembangan jasmani dan rohani agar anak memiliki kesiapan dalam memasuki pendidikan lebih lanjut [3].

Perkembangan anak di PAUD sangat dipengaruhi oleh faktor eksternal dan internal seperti lingkungan belajar, kemampuan guru mengelola kelas, metode dan media pembelajaran yang digunakan, motivasi belajar anak, keterlibatan orangtua dalam mendukung pembelajaran anak. Contoh bentuk keterlibatan orangtua dalam mendukung belajar anak adalah dengan menciptakan komunikasi yang baik antara guru dan orangtua wali siswa. Komunikasi ini harus bersifat dua arah agar orangtua mengetahui perkembangan anak di sekolah dan dapat mendukungnya diluar sekolah. Pendapat senada dikemukakan oleh Mc. Carty, Brennan and Vecchiarello yang menyatakan bahwa salah satu faktor yang sangat penting adalah adanya kerjasama yang baik antara orang tua dan sekolah [4]. "IDEA 2004 dan No Child Left Behind 2001 sebuah Lembaga kongres di Amerika Serikat mengharuskan sekolah untuk mengubah kebiasaan tradisional tentang keterlibatan orang tua dari menandatangani dan mengambil rapor, membaca buletin, dan mendampingi pesta liburan, untuk memasukkan kegiatan seperti berpartisipasi dalam proses pengambilan keputusan sekolah, memberikan masukan kepada guru tentang bagaimana membantu anak mereka, dan membentuk kemitraan yang bermakna dengan komunitas sekolah"[5]. Ini membuktikan jika orangtua juga harus berperan serta dalam pengawasan terhadap anak dan memiliki peran yang sangat penting di dalam tumbuh kembang anak. 
Bukan hanya orangtua, seorang pendidik PAUD juga diharuskan memiliki empat kompetensi dasar, diantaranya kompetensi Pedagogik, kompetensi Kepribadian, kompetensi Sosial, dan kompetensi Profesional. Berdasarkan Undang-Undang No 14 tahun 2005, ke empat kompetensi dasar tersebut harus dimiliki oleh setiap pendidik paud, agar pendidik dapat menjalankan tugasnya dengan baik, sesuai dengan tugas-tugas keprofesionalannya [6]. Kompetensi sosial adalah kemampuan guru dalam bergaul dan berkomunikasi dengan lingkungan sekitarnya yaitu peserta didik, tenaga pendidik dan kependidikan, orangtua wali siswa dan masyarakat sekitar. Komunikasi antara orang tua dan guru biasanya berupa pertukaran informasi dan ide tentang pengembangan dan perkembangan anak di sekolah dan di rumah [7]. Orang tua merupakan mitra kerja bagi guru dalam Pendidikan anak. Komunikasi yang baik sangat dibutuhkan agar keduanya dapat menyamakan persepsi terkait hal-hal yang dibutuhkan dalam Pendidikan dan perkembangan anak. Orang tua dan guru harus saling membantu dan mencari solusi bersama jika ditemukan permasalahan di sekolah ataupun di rumah.

Pandemi covid 19 yang sedang terjadi juga mengharuskan terjalinnya komunikasi yang erat antara orang tua dan guru di sekolah anak usia dini. Tidak sedikit guru yang merasa kebingungan untuk membagikan materi pembelajaran. Pada akhirnya guru hanya membagikan tugas dan materi melalui orang tua siswa. Realitas di lapangan ditemukan jika kurangnya komunikasi antara orangtua dan guru yang menyebabkan persoalan kecil dan bahkan celah antara orangtua dan guru.

Masih banyak orang tua yang masih menyalahkan guru ketika dihadapkan pada kondisi dan situasi anak yang tidak dapat memahami pelajaran dengan baik. Masih banyaknya orang tua yang merasa bahwa proses perkembangan dan pendidikan anak adalah tanggung jawab mutlak dari guru di sekolah. Demi terlaksananya komunikasi dua arah ini, perlu adanya sarana yang dapat memfasilitasi hal tersebut. Masalah lain yang ditemukan dilapangan adalah adanya kebijakan yang mengubah pembelajaran luring atau tatap muka antara guru dengan siswa sebagaimana yang biasanya dilakukan oleh guru dan siswa didalam kelas diganti menjadi dilakukan dengan jarak jauh menggunakan sistem daring/online. Serta kurangnya ketidakmampuan orang tua untuk memahami materi dan tugas yang telah diberikan guru. Keluhan lain yaitu orang tua merasa kesulitan mendampingi anak belajar karena belum paham caranya, tidak biasa menggunakan teknologi digital untuk pembelajaran anak, tidak memahami maksud pesan yang disampaikan guru, dan lainnya.

Maka dari itu agar pembelajaran siswa tetap bisa berlangsung dengan maksimal, pendidik dituntut untuk berupaya memaksimalkan pembelajaran jarak jauh menggunakan sistem online/daring, dengan menggunakan e-learning sebagai salah satu media pembelajaran dengan memanfaatkan akses internet, disamping itu pendidik juga dipaksa untuk merubah model/strategi pembelajaran menjadi digital. Dalam penggunaan Elearning pendidik harus betul-betul mempertimbangkan beberapa hal misalnya: kemampuan siswa dalam teknologi, kondisi/latarbelakang orang tua, dan sarana 
prasarana yang ada, hal tersebut perlu dilakukan agar nanti ketika sudah menggunakan perangkat yang dipilih tidak menimbulkan masalah baru

Salah satunya dengan adanya media sosial. Media sosial merupakan salah satu program pada alat komunikasi HP android terbaru dan terkini yang membuat layanan komunikasi dengan beberapa orang tua wali siswa menjadi satu kesatuan dengan cepat dan mudah sehinngga informasi apapun baik mengenai program, kegiatan, undangan dan evaluasi siswa dapat disampaikan melalui media sosial pada zaman sekarang [8]. Salah satu aplikasi yang sering digunakan dalam berkomunikasi antar dua orang atau lebih adalah Aplikasi Whatsapp Group. Aplikasi Whatsapp Group berada di dalam WhatsApp Messenger. Whatsapp Messenger merupakan aplikasi pesan lintas platform yang memungkinkan kita bertukar pesan tanpa pulsa, karena WhatsApp Messenger menggunakan paket data internet. Aplikasi WhatsApp Messenger menggunakan koneksi internet 3G, 4G atau WiFi untuk komunikasi data. Dengan menggunakan WhatsApp, kita dapat melakukan obrolan daring, berbagi file, bertukar foto dan lain-lain [9]. Pentingnya penggunaan Whatsapp Group ini demi terjalinnya daya komunikasi yang lebih cepat, terjalinnya tali silaturahmi antara orangtua siswa dan pihak sekolah dan menciptakan kebersamaan persepsi antara guru dan orang tua demi kelangsungan dan kebaikan Pendidikan dan perkembangan anak. Dengan memanfaatkan aplikasi WhatsApp ini guru bisa berinteraksi dan berkomunikasi kepada orang tua untuk memberikan informasi dan melakukan proses pembelajaran dengan efektin dan tepat sasaran.

Pendapat diatas juga didukung dengan penelitian dari Imam Jafar Shodiq (2020) yang mengungkapkan jika pemanfaatan WhatsApp sebagai media pembelajaran ditengah pandemi covid 19 seperti saat ini sangatlah tepat, mengingat aplikasi ini sangat sederhana bila dibandingkan dengan aplikasi online lainnya, mudah dalam pengoperasiannya dan tentunya memiliki fitur-fitur yang banyak. Selain sebagai media pembelajaran pemanfaatan WhatsApp dalam aktivitas edukasi bertujuan sebagai sarana edukasi, sebagai sarana evaluasi, sebagai sarana penyambung informasi, dan sebagai sarana layanan konsultasi dan menjalin silaturahim [10]. Penelitian Eka Susilowati (2020) juga menyebutkan jika penggunaan whatsApp sebagai media pembelajaran selama masa pandemic memberikan efek yang baik. Media grup WhatsApp ini mendorong setiap siswa untuk ikut berpartisipasi aktif/ berdiskusi. Selain itu, siswa dapat dengan mudah memperoleh informasi, berupa file materi pembelajaran, foto penyelesaian soal-soal, penjelasan melalui chat atau voice note sehingga siswa tidak perlu mencatat. Diskusipun berjalan lancer dan saling memberikan umpan balik pertanyaan dan jawaban sehingga siswa semakin mengerti materi yang diberikan [11].

Maka dari itu penelitian ini bertujuan untuk melihat bagaimana pemanfaatan whatsapp group dikalangan orang tua dan guru PAUD. Sebagaimana kita ketahui jika anak usia dini masih fokus pada kegiatan bermain sambil belajar dan perlunya dukungan dan pendampingan orang tua dalam pembelajaran daring. 


\section{Metode Penelitian}

Metode yang digunakan dalam penelitian ini adalah deskriptif kualitatif. Penelitian deskriptif kualitatif adalah metode penelitian yang berlandaskan pada filsafat postpositivisme yang biasanya digunakan untuk meneliti pada kondisi objektif yang alamiah dimana peneliti berperan sebagai instrumen kunci [12]. Pendekatan yang digunakan dalam penelitian ini adalah pendekatan kualitatif. Penelitian kualitif adalah penelitian yang menggunakan latar alamiah, dengan maksud menafsirkan fenomena yang terjadi dan dilakukan dengan jalan melibatkan berbagai metode yang ada [13]. Penelitian kualitatif adalah penelitian yang datanya dikumpulkan bukan berupa angka angka, melainkan data tersebut berasal dari naskah wawancara, catatan lapangan, dokumen pribadi, catatan, memo, dan dokumen resmi lainnya [14].

Subjek penelitian ini adalah Kepala sekolah, guru kelas PAUD, orang tua siswa PAUD di Desa Tembung Kecamatan Percut Sei Tuan Kabupaten Deli Serdang Provinsi Sumatera Utara. Subjek penelitian dipilih dengan cara purposive sampling. Teknik Purposive Sampling artinya peneliti mengambil narasumber dengan teknik pengambilan sampel sumber data dengan pertimbangan tertentu [15].

Proses pengumpulan data akan dilakukan melalui observasi, wawancara dan studi pustaka. Pada proses observasi, peneliti akan berperan serta ke lapangan untuk mengamati objek penelitian dan berinteraksi dalam komunikasi grup tersebut. Adapun hal yang akan menjadi focus peneliti adalah isi/konten dari komunikasi grup tersebut dan pemanfaatan grup tersebut. Teknik ini digunakan penulis agar dapat melihat secara terbuka objek untuk mendapatkan data lapangan yang dapat dilihat penginderaan. Proses wawancara digunakan peneliti untuk mengetahui hal-hal yang lebih mendalam agar dapat menginterprestasikan fenomena yang terjadi yang tidak didapatkan melalui observasi. Studi Pustaka dilakukan untuk mengumpulkan sejumlah data teoritis yang berhubungan dengan permas. alahan penelitian.

Analisis data kualitatif dilakukan apabila data empiris yang diperoleh adalah data kualitatif berupa kumpulan berwujud kata-kata dan bukan rangkaian angka. Analisis kualitatif terdiri dari tiga Langkah, yaitu: reduksi data, penyajian data dan penarikan kesimpulan [16].

\section{Hasil dan Pembahasan}

\subsection{Karakteristik Penggunaan Media Sosial di Kalangan Guru PAUD dan Orang Tua Siswa}

Media sosial bukan hal yang baru lagi untuk masyarakat Indonesia. Setiap kegiatannya tidak dapat dipisahkan oleh penggunaan media sosial. Begitupun di kalangan para orang tua dan guru PAUD. Media sosial dimanfaatkan oleh para orang tua dan guru PAUD baik untuk kegiatan pekerjaan maupun kegiatan keseharian. Adapun persentase media sosial yang paling sering digunakan oleh para orang tua dan guru PAUD terlihat pada gambar 1 dibawah ini: 


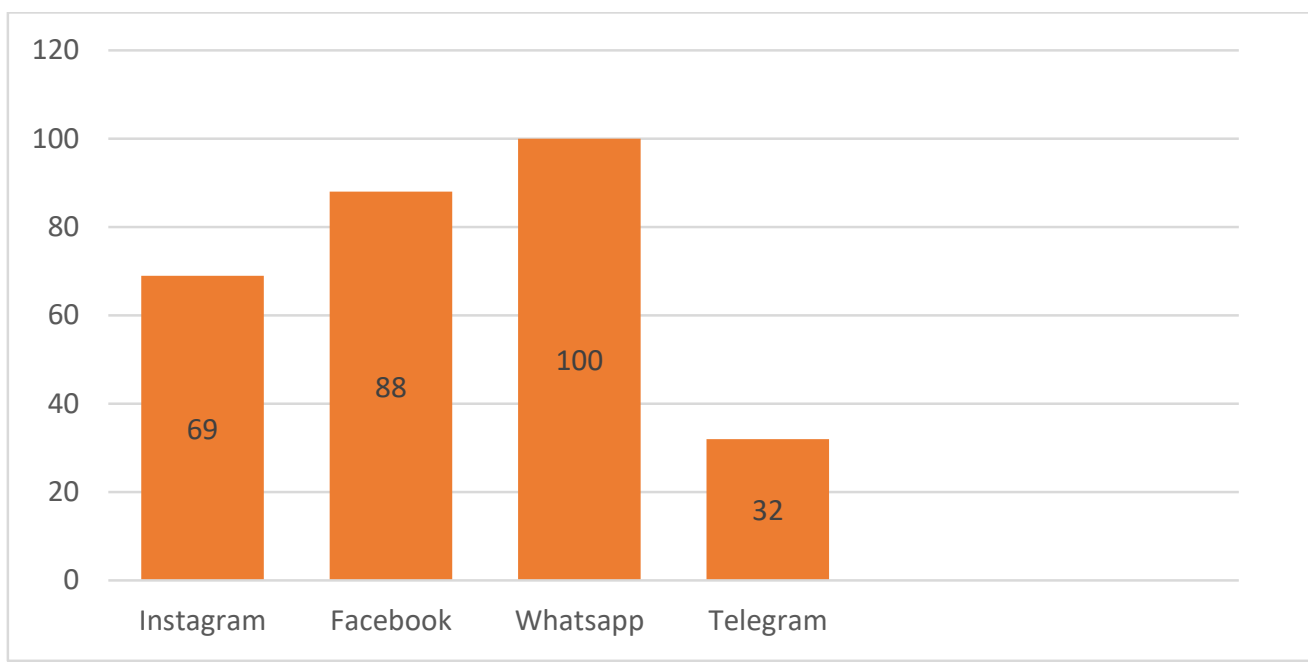

Gambar 1. Persentase Penggunaan Media Sosial Oleh Orang Tua dan Guru PAUD di Desa Tembung Kecamatan Percut Sei Tuan Kabupaten Deli Serdang Provinsi Sumatera Utara

Dari gambar diatas dapat ditarik kesimpulan jika Whatsapp adalah aplikasi yang digunakan oleh semua orang tua dan guru PAUD. Kemudian Facebook menjadi aplikasi kedua yang paling banyak digunakan dan disusul oleh Instagram dan Telegram. Ini menunjukkan jika aplikasi Whatsapp paling tepat digunakan sebagai sarana komunikasi orang tua dan guru dikarenakan seluruh orang tua dan guru PAUD memiliki Whatsapp Account. Dari sudut pandang fungsi, Whatsapp adalah aplikasi perpesanan instan untuk smartphone. Whatsapp hampir sama dengan aplikasi SMS yang biasa kita gunakan di ponsel lama. Tetapi Whatsapp tidak menggunakan pulsa, itu menggunakan data internet. Selama data internet mencukupi, tidak ada batasan untuk melakukan komunikasi. Menggunakan aplikasi Whatsapp sangat berguna untuk menjaga komunikasi komunitas kita. Jika memiliki beberapa informasi tentang komunitas, atau menyelenggarakan acara komunitas, maka informasi ini akan dengan mudah dibagikan di grup tersebut.

Aplikasi Whatsapp juga memiliki fitur untuk membuat grup dimana fitur grup ini dapat digunakan oleh orang tua dan guru dalam berbagi informasi terkait pertumbuhan dan perkembangan anak di sekolah maupun di rumah.

Observasi yang dilakukan peneliti menemukan jika tiap grup di setiap PAUD di Desa Tembung berisi 10 sampai dengan 15 orang yang terdiri dari 3 sampai dengan 4 guru PAUD dan 7 sampai dengan 10 siswa PAUD. Grup ini dikelola langsung oleh guruguru tersebut. Setiap pergantian tahun ajaran baru maka grup ini akan dihapus oleh guruguru tersebut dikarenakan siswa yang sudah lulus dari PAUD.

\subsection{Pemanfaatan Whatsapp Group Sebagai Media Komunikasi Selama Masa Pandemi Covid 19}

Pandemi covid 19 yang terjadi di hampir seluruh belahan dunia membawa dampak yang cukup serius. Bukan hanya dari segi ekonomi, kesehatan dan sosial yang terkena dampaknya tetapi semua aspek mendapat efek dari pandemi covid 19 termasuk 
segi pendidikan, semua jenjang pendidikan menghentikan kegiatan pembelajaran secara tatap muka dan berganti dengan sistem daring atau belajar jarak jauh. Ini menuntut guru agar menjadi kreatif dalam menyampaikan materi pembelajaran. Guru bukan satusatunya tonggak penentu. Ini tantangan berat bagi guru maupun orang tua. Tak sedikit orangtua pun mengeluhkan penggunaan media pembelajaran jarak jauh melalui daring (internet) ini. Terlebih bagi orang tua yang work from home (WFH), harus tetap mendampingi anak-anaknya, khususnya anaknya yang masih usia dini.

Pemanfaatan media sosial grup WhatsApp bisa menjadi salah satu jalan keluar dalam masalah diatas. Dikarenakan hampir semua orang tua dan guru di PAUD sudah menggunakan dan familiar dengan penggunaan WhatsApp. Adapun pemanfaatan grup whatsapp adalah sebagai berikut: (1) Grup WhatsApp dapat dijadikan sarana edukasi. Yaitu dengan cara semua anggota grup secara aktif mengkomunikasikan informasi di grup WhatsApp tersebut. Anggota ini adalah guru dan orang tua siswa. Guru sebagai pendidik memegang peranan paling penting dalam proses penyampaian informasi dalam kelompok, diantaranya informasi yang berkaitan dengan pembelajaran, pertumbuhan tiap anak, perkembangan anak baik dalam hal motorik halus dan motorik kasar.

(2) Grup WhatsApp dapat dijadikan sarana penyambungan informasi. WhatsApp tidak hanya sekedar sebagai media pembelajaran bagi peserta didik, akan tetapai juga dapat dijadikan sebagai sarana penyambung informasi - informasi kepada siswa ataupun kepada orang tua peserta didik. Dengan demikian dengan adanya aplikasi whatsapp sangat membantu pihak sekolah dalam memberikan informasi yang sangat cepat, apalagi dalam kondisi pandemi saat ini arus informasi sangatlah cepat berubah, sehingga terkadang pihak sekolah harus dengan cepat menginformasikan kepada peserta didik atau orang tau peserta didik. Bukan hanya itu, juga terkait dengan info hari libur, hari hari besar dan kegiatan kegiatan yang akan diadakan disekolah.

(3) Grup WhatsApp dapat dijadikan sarana silaturahmi dan layanan konsultasi. Whatsapp grup juga bisa dijadikan sarana konsultasi bagi orang tua dan guru dan sarana menjalin sillaturahmi guru dengan orang tua. Adanya WhatsApp grup ini jelas sangat membantu bagi para orang tua dalam memantau perkembangan anaknya, apalagi orang tua yang sibuk dengan pekerjaannya tentu disela-sela istirahatnya bisa memanfaatkan aplikasi WA untuk bersilaturrohin dengan pendidik, bisa bercerita tentang permasalahan anaknya dan bediskusi terkait perkembangan anak didiknya tanpa harus datang ke sekolah.

Jika melakukan komunikasi dengan tatap muka maka pada umumnya guru dan orang tua menggunakan waktu 10-19 menit dalam membicarakan perkembangan anak. Tetapi dengan pemanfaatan grup Whatsapp sebagai salah satu sarana komunikasi guru dan orang tua mempermudah komunikasi tersebut terjalin dan komunikasi dapat dilakukan dimana saja dan kapan saja. Menurut hasil pengamatan dan wawancara yang dilakukan kepada guru menunjukkan bahwa hampir 90\% orang tua perhatian dan focus terhadap apapun informasi dan berita yang dibagikan oleh guru di dalam grup. Ini akan 
mempermudah perkembangan anak dikarenakan adanya kerjasama yang baik antara orang tua dan guru dalam mendidik dan mengajarkan anak di rumah maupun di sekolah.

(4) Grup WhatsApp dapat dijadikan sarana evaluasi. Seperti yang kita ketahui jika penggunaan media tersebut merupakan salah satu jalan yang tepat dalam rangka mengevaluasi dan mengembangkan anak, khususnya pengendalian perkembangan anak di sekolah. Begitupun penggunaan grup Whatsapp mempermudah guru dalam melaporkan setiap kegiatan anak dan memudahkan komunikasi antara orang tua dan guru terkait hal-hal yang menyangkut tumbuh kembang anak. Pemanfaatan media grup Whatsapp ini juga memberikan efek kepada berkurangnya penggunaan kertas yang biasa digunakan sebagai penyampai informasi berita dan harus ditempelkan di mading (majalah dinding). Tetapi ditemukan juga jika banyaknya orang tua yang merasa tidak nyaman ketika guru melaporkan perkembangan dan kegiatan anak mereka di dalam grup. Menurut beberapa orang tua, hal-hal tersebut sangatlah bersifat privasi dan seharusnya dilaporkan secara langsung kepada orang tua anak tersebut. Tetapi grup whatsapp bukanlah satu satunya media pelaporan kegiatan dan perkembangan anak di sekolah tetapi setiap bulannya guru PAUD juga melakukan pelaporan dan pencatatan yang akan dilaporkan kepada orang tua dalam bentuk portofolio proses ataupun portofolio produk.

Maka dari penjelasan diatas perlunya membangun komunikasi yang positif antara orang tua dan guru selama masa pandemic covid 19 ini. Pentingnya komunikasi antara orang tua dan guru, terutama untuk memastikan anak-anak belajar secara efektif dan mendapatkan yang terbaik bagi pertumbuhan dan perkembangan karakter anak selama masa pandemi. Agar memudahkan komunikasi kepada orang tua siswa maka ada 3 hal yang harus diperhatikan oleh guru yaitu (1) Kejelasan, sebaiknya guru menggunakan Bahasa yang mudah dipahami dan memberikan intruksi penyelesaian tugas siswa dengan jelas, guru juga harus memberikan waktu bertanya kepada orang tua dan menjawab dengan sedetail mungkin dengan menggunakan Bahasa yang mudah dipahami oleh orang tua (2) Konsistensi, guru harus memiliki sikap objektif terhadap setiap anak dan tidak membanding-bandingkan anak yang satu dengan yang lainnya secara terang-terangan di dalam grup (3) Perduli, guru diharapkan perduli terhadap kenyamanan orang tua dan kemajuan siswa selama pembelajaran daring berlangsung [17].

Dengan mengaplikasikan komunikasi positif ini maka pertukaran informasi akan berlangsung dengan sangat baik dan terjadi perubahan sikap dan terjalinya komunikasi yang baik antara guru dan orang tua siswa. Dengan begitu terjadi pemahaman yang sama antara orang tua dan guru, menimbulkan kesenangan dikedua belah pihak, terjalinnya hubungan sosial yang baik dan akan mempengaruhi tindakan kedua pihak untuk kedepannya.

\section{Kesimpulan}

Hampir seluruhnya orang tua dan guru sudah familiar dalam menggunakan WhatsApp sebagai media dalam berkomunikasi maka bukan hal yang baru lagi. Hal tersebut memudahkan komunikasi antara guru dan orang tua sehingga terjalinnya komunikasi yang positif dan guru dan orang tua dapat bersama memantau perkembangan 
anak. Pemanfaatan whatshapp sebagai media pembelajaran ditengan pandemi covid 19 seperti saat ini tepat, mengingat aplikasi ini sangat sederhana, mudah dalam pengoperasiannya dan tentunya memiliki fitur-fitur yang banyak Selain sebagai media pembelajaran pemanfaatan whatsapp dalam aktivitas edukasi bertujuan sebagai sarana edukasi, sebagai sarana evaluasi, sebagai sarana penyambung informasi, dan sebagai sarana layanan konsultasi dan menjalin silaturahmi.

Namun ada beberapa hal yang harus diperbaiki yaitu kurang cepatnya respon orang tua dalam menjawab dan memperhatikan informasi yang sering dibagikan di Whatsapp Grup dan seringnya "spam” yang menjadikan banyaknya informasi yang tidak terbaca oleh orang tua. Solusi yang dapat dilakukan adalah dengan membatasi pengguna/anggota yang dapat mengirimkan pesan ke grup WhatssApp, mengatur hanya admin yang dapat mengirimkan pesan, memberikan peraturan yang harus dipahami dan dipatuhi oleh semua anggota grup dan admin harus aktif dan cepat menghapus semua hal yang tidak berhubungan dan tidak berkaitan dengan pembelajaran dan perkembangan anak disekolah agar grup menjadi lebih rapi dan orang tua siswa mendapatkan informasi yang dibutuhkan.

\section{DAFTAR PUSTAKA}

[1] Undang Undang Republik Indonesia No. 20 Tahun 2003

[2] Permendikbud 137-2014 Standar Nasional PAUD

[3] Undang Undang Republik Indonesia No. 20 Tahun 2003

[4] Peter. J.Mc, Liran. B, Karen, Vecchiarello. Parent-School Communication in the Inclusive Classroom: A Comprehensive Model of Collaboration in Education. 2011. International Journal of Humanities and Social Science, Vol. 1 No. 15, 55.

[5] Kochhar. B. Parents as Partners: What is the Role of Families in School Collaboration and System Coordination? In Collaboration and System Coordination for Students with Special Needs. 2008. (pp.204- 220). New Jersey: Prentice Hall.

[6] Undang Undang No. 14 Tahun 2005

[7] Symeou. L, Roussounidou. E, and Michaelides. M. I Feel Much More Confident Now to Talk With Parents": An Evaluation of In-Service Training on Teacher-Parent Communication. School Community Journal, Vol. 22, No. 1 (2012), 65

[8] Warsita. B, Teknologi Pembelajaran Landasan dan Aplikasinya. Jakarata: Rineke Cipta, 2008. hlm. 62.

[9] Hartanto, AAT. Panduan Aplikasi Smartphone, Jakarta. Gramedia Pustaka Utama, 2010. hlm. 100. 
[10] Shodiq, I.J. dan Zainiyati, H.S. Pemanfaatan Media Pembelajaran E-Learning Menggunakan Whastsapp Sebagai Solusi Ditengah Penyebaran Covid-19 Di Mi Nurulhuda Jelu. Jurnal Al-Insyiroh, Vol. 6, No. 2 (2020), hlm. 144-159

[11] Susilowati, E. Bagaimana Pembelajaran Daring di Tengah Wabah Covid 19 melalui Grup WhatsApp?. Jurnal Pendidikan Matematika Raflesia, Vol. 5, No. 3 (2020), hlm. 1-25

[12] Sugiyono. Metode Penelitian Kuantitatif Kualitatif dan R\&D. Bandung: ALFABETA. 2008

[13] Denzin, Norman K. dan Yvonna S. Lincoln. Handbook of Qualitative Research. Terj. Dariyatno dkk. Jogjakarta: Pustaka Pelajar. 2009.

[14] Moleong, Lexy. Metode Penelitian Kualitatif. Bandung. PT. Remaja Rosda Karya. 2007.

[15] Moleong, Lexy. Metode Penelitian Kualitatif. Bandung. PT. Remaja Rosda Karya. 2007.

[16] Miles, B. Mathew dan Michael Huberman. Analisis Data Kualitatif Buku Sumber Tentang Metode-metode Baru. Jakarta: UIP. 1992

[17] pauddikmassumut.kemdikbud.go.id 